\title{
YHTEISKUNNAN VALTAVA VATUPASSI
}

\begin{abstract}
Richard Wilkinson \& Kate Pickett: The Spirit Level. Why Equality is Better for Everyone. Penguin Books, London et al. 2010 (2. muokattu painos).
\end{abstract}

Viime vuosina monien vasemmistolaisten huolenaiheena on ollut lisääntyvä yhteiskunnallinen eriarvoisuus. Totta onkin, että taloudellinen eriarvoisuus lisääntyi 1990-luvun lamaa seuranneiden leikkausten ja pääomatulojen kasvun myötä. Kansainvälisessä katsannossa Suomi on edelleen kuitenkin yksi maailman tasa-arvoisimpia maita muiden Pohjoismaiden ja Japanin ohella. Monet ovat alkaneet myös pohtia sitä, onko taloudellisella kasvulla ja hyvinvoinnilla varsinaista yhteyttä sen jälkeen, kun tietty peruselintaso on saavutettu. Epidemiologit Richard Wilkinson ja Kate Pickett esittävät tuoreessa kirjassaan, että esimerkiksi taloudellisen kasvun ja elinajanodotteen välinen yhteys ei ole ollenkaan selvä asia rikkaiden länsimaiden tapauksessa. Näyttää nimittäin siltä, että kun tietty peruselintaso on saavutettu, ei lisääntyvällä materiaalisella hyvinvoinnilla välttämättä ole vaikutusta yleiseen hyvinvointiin. Tämän lähtökohtaoletuksen tueksi Wilkinson ja Pickett käsittelevät runsaasti terveyssosiologista dataa ja he myös esittävät kiinnostavia sosiaalipsykologisia ja yhteiskuntafilosofisia väitteitä tasa-arvon ja sosiaalisen vertailun merkityksestä ihmisyhteisöissä.

Ihmiskunnan historia voidaan tunnetusti esittää pelkistetyssä muodossaan seuraavasti: ensin meitä vaivasivat köyhyydestä johtuvat sairaudet (ja kehitysmaat kärsivät näistä yhä), kun taas viime vuosikymmeninä niin sanotut elintasosairaudet (syövät ja sydän- ja verisuonitaudit) ovat olleet riesana etenkin länsimaissa.
Wilkinsonin ja Pickettin pääväite kuuluu, että taloudellinen epätasa-arvoisuus - siis suuret tuloerot - korreloi vahvasti kaikenlaisten terveydellisten ja sosiaalisten ongelmien kanssa. Siis mitä suuremmat tuloerot yhteiskunnassa vallitsevat, sitä enemmän on myös ongelmia. Terveydelliset ja sosiaaliset ongelmat tulee tässä tapauksessa käsittää hyvin laajasti, sillä niihin kuuluvat muun muassa alhaisempi elinikä, alhainen luottamus, psyykkiset ongelmat, ylipaino, teiniraskaudet sekä väkivallan määrä. Keskeistä ei niinkään ole se, mikä kenenkin tulo- ja elintaso sattuu olemaan, vaan se, mikä oma sosiaalinen asema on suhteessa muiden asemiin. Wilkinson ja Pickett vertailevat väitteidensä tueksi useita eri maita ja myös Yhdysvaltojen eri osavaltioita keskenään. Lisäksi he esittävät sosiaalipsykologisen teorian, jossa sosiaalinen vertailu on keskeinen inhimillinen ominaisuus. Empiirisenä pohjana tälle teorialle on paradoksaalinen aikalaisdiagnostinen havainto, jonka mukaan sekä ahdistuneisuus että itsetunto ovat lisääntyneet viime vuosikymmeninä. Lisääntyneen itsetunnon voisi kuvitella olevan hyvä asia, mutta voikin olla, että "lisääntynyt ahdistuneisuus siitä, miten muut meidät näkevät ja mitä muut meistä ajattelevat, on osaltaan tuottanut eräänlaisen puolustusreaktion" (s. 36). Tämä reaktio näkyy itsen korostamisena ja epävarmana egoismina, joka saattaa äkkiseltään vaikuttaa hyvältä itsetunnolta, mutta ei sitä aidosti ole. Viime vuosikymmeninä tapahtunut stressitason nousu - joka voidaan havaita jopa hormonaalisella tasolla - on järkevä reaktio tilanteessa, jossa toiminnan ympäristö on hyvin epävarma (tai jopa vaarallinen), mutta pitkittyessään tällainen jatkuva stressi saattaa aiheuttaa monenlaisia terveydellisiä ongelmia.

Sosiaaliseen asemaan liittyvä ahdistuneisuus voi johtua alhaisesta sosiaalisesta statuksesta, ystävien puutteesta tai varhaiseen elämään liittyvästä stressistä, ja tällainen ahdistuneisuus on Wilkinsonin ja Pickettin mukaan sitä yleisempää, mitä suuremmat sosiaaliset erot yhteiskunnassa sattuvat vallitsemaan. Vielä kiinnostavampi väite kuuluu, että ainoastaan huonoimmassa asemassa olevilla ei mene huonosti epätasa-arvoisissa yhteiskunnissa, vaan myös parempiosaiset kärsivät yhteiskunnan yleisestä epätasa-arvosta. Siis niin hyvä- kuin huono-osaiset joutuvat murehtimaan omaa sosiaalista asemaansa taloudellisen epätasa-arvon vallitessa. Se, että myös hyväosaiset "kärsivät" epätasa-arvoisemmissa olosuhteissa voidaan havaita muun muassa siitä, että "vaikka vanhempasi olisivat hyvin koulutettuja - ja oletettavasti korkean sosiaalisen statuksen omaavia-niin maa, jossa asut, vaikuttaa koulutukselliseen menestykseesi" (s. 108). Taloudellisesti tasa-arvoisemmissa maissa kaikilla siis menee koulussa paremmin.

Miten Suomi sitten sijoittuu Wilkinsonin ja Pickettin vertailuissa? Tulonjaon tasa-arvoisuudessa Suomi on samassa porukassa muiden Pohjoismaiden ja Japanin kanssa, kun toisesta päästä asteikkoa löytyvät muun muassa sellaiset maat kuin IsoBritannia, Portugali, Singapore ja Yhdysvallat. Esimerkiksi lasten kokemien konfliktien alhaisessa määrässä Suomi on aivan omaa luokkaansa - jopa Ruotsissa konflikteja koetaan Suomea enemmän. Sosiaalinen liikkuvuus taas on Suomessa ja muissa Pohjoismaissa vähäisen epätasa-arvon ennustamalla 
korkealla tasolla, kun taas Yhdysvalloissa, joissa ideologinen hokema väittää kenen tahansa pystyvän saavuttamaan "amerikkalaisen unelman", on sosiaalinen liikkuvuus huomattavasti harvinaisempaa.

Joitakin muuttujia tarkasteltaessa Suomi toimii esimerkkinä siitä, että kaikilta osin asiat eivät ole niin yksinkertaisia kuin Wilson ja Pickett olettavat. Esimerkiksi ylipainoisten osuus Suomessa on samaa tasoa kuin Portugalissa (noin 20 prosenttia), vaikka Portugali on taloudellista tasa-arvoa mitattaessa aivan toisessa päässä skaalaa. Toinen seikka, jossa Suomi ei erotu edukseen, koskee - jossain määrin odotetusti - henkirikoksia. Suomen henkirikosluvut nimittäin ovat samaa tasoa Israelin kanssa, joka taas on taloudellisessa tasa-arvossa Suomea huomattavasti jäljessä. Wilkinson ja Pickett spekuloivat, että selitys tälle havainnolle löytyisi ampuma-aseiden suhteellisen suuresta määrästä Suomessa. Tätä selitystä tukee osaltaan se, että Singaporessa aseita omistetaan vähän ja siellä tehdään myös henkirikoksia huomattavasti vähemmän kuin mitä maan taloudellinen epätasa-arvoisuus antaisi odottaa.

Aseiden määrään liittyvä selitys voi osin olla pätevä, mutta kuva muodostuu toisenlaiseksi, jos katsotaan tarkemmin sitä, minkälaisella välineellä henkirikokset Suomessa yleensä tehdään (Wilkinson ja Pickett eivät itse tarkastele asiaa lähemmin). Tällöin saadaan tulokseksi, että Suomessa turvaudutaan yleensä veitsiin (n. $40 \%$ henkirikoksista; ampuma-aseet vain 16\%) ja kyse on hyvin usein ryyppyporukoissa pikaistuksissa tehdyistä tapoista. Sinällään tämä havainto ei sodi Wilsonin ja Pickettin yleisiä väkivaltaa koskevia oletuksia vastaan, sillä heidän mukaansa väkivallan yllykkeet löytyvät todellisista tai kuvitelluista uhista omalle ylpeydelle. Näin ollen sosiaaliset emootiot eli nöyryytyksen tai häpeän tunteet ovat omiaan johtamaan väkivaltaiseen "kunnianpalautukseen". Tällaiset tunteet lienevät myös ryyppyporukoiden välienselvittelyjen taustalla.

Kirjan keskeinen ongelma on se, että Wilkinson ja Pickett tarkastelevat selittävänä muuttajana vain tulonjakoa eivätkä huomioi monia muita tasa-arvoon vaikuttavia tekijöitä. On selvää, että esimerkiksi koulutus on keskeinen selittäjä, kun tarkastellaan vaikka sosiaalisia terveyseroja (siis koulutetut voivat kaikin tavoin paremmin). Koulutus luonnollisestikin korreloi tulojen kanssa (turhan heikosti, saattaa jokunen tämän lehden lukijoista tuhahdella), mutta koulutus ei kuitenkaan palaudu tulotasoon. Wilkinson ja Pickett ovat jossain määrin tietoisia näistä ongelmista. He esittävät, että materiaalista epätasa-arvoa voisi ajatella "luurankona tai kehikkona, jonka ympärille luokkaerot ja kulttuuriset erot muodostuvat" (s. 28). Materiaalinen epätasaarvoisuus on tällöin pohja, jonka päälle erot esimerkiksi pukeutumisessa, esteettisessä maussa ja koulutuksessa kasautuvat ajan kuluessa. Tämä väite saattaa joissain tapauksissa olla osuva, mutta yleisenä mallina on kuitenkin liian yksinkertaistavaa nojautua tällaiseen historialliselta materialismilta haiskahtavaan skeemaan, jossa talous on perusta ja kulttuuri vain päällysrakenne. Asia on huomattavasti monimutkaisempi, sillä kulttuuriset tekijät saattavat näytellä jopa itsenäistä rooliaan. Esimerkiksi bourdieulaiset tutkijat toteaisivat, että kulttuurin ja talouden kentät ovat kyllä yhteydessä toisiinsa, mutta molemmilla on silti suhteellinen itsenäisyytensä.

Wilsonin ja Pickettin puolustukseksi voidaan väittää, että mallista saattaisi tulla hyvin monimutkainen, jos nämä kulttuuriset tekijät pyrittäisiin ottamaan huomioon tasa-arvon astetta mitatessa - ainakin niin monimutkainen, että sen pohjalta olisi vaikea esittää yksinkertaisia kuvioita tai yhteiskuntapoliittisia iskulauseita. Yksinkertaistavuudesta huolimatta kirja on kuitenkin laaja-alainen, ajankohtainen ja empiiriseen tutkimukseen perustuva yhteiskuntapoliittinen puheenvuoro, jollaisia näkisi mielellään enemmänkin - etenkin kun nykyään erilaisia pamfletteja ilmestyy niin paljon, että niitä voi jo käyttää peflettinä. Todettakoon myös, että juuri tulonjakokysymyksiä on järkevä nostaa esiin yhteiskuntapoliittisessa keskustelussa, koska tulonjakoon on suhteellisen helppo vaikuttaa muun muassa verotuksen keinoin.

Wilkinsonin ja Pickettin kirja tarjoaakin hyviä vasta-argumentteja nykytrendille, jossa tuloverotuksen progressiota lähinnä loivennetaan. Ja vaikka Wilkinsonin ja Pickettin väitteiden yksinkertaistavuus olisikin jossain määrin ongelmallista, niin silti vaikuttaa järkevältä olettaa, että tasa-arvoisemmissa konteksteissa on helpompi samaistua ja luottaa muihin kuin sellaisissa tilanteissa, joissa sosiaaliset erot ovat niin suuret, että sosiaalinen asema tuntuu yhteistä ihmisyyttä tärkeämmältä seikalta. Statusasemiin kiinnitetään erityistä huomiota ja niistä kilpaillaan silloin, kun selviä statuseroja on ylipäätään olemassa. Sosiaalisen kurjuuden suhteellisuutta tarkasteltaessa ei kuitenkaan tulisi unohtaa sitä seikkaa, että kurjuus on kehitysmaissa edelleen myös absoluuttista. 